\title{
Verbum
}

30 (2016) $53-78$

Ks. Wojciech Pikor

Uniwersytet Mikołaja Kopernika, Toruń pikorwo@wp.pl

\section{DYNAMIKA „PRZYMIERZA POKOJU” W KSIĘDZE EZECHIELA}

The Dynamics of the „Covenant of Peace” IN THE BOOK OF EZEKIEL

Idea przymierza pokoju, występująca w tekstach starożytnego Bliskiego Wschodu, w Biblii Hebrajskiej pojawia się w tekstach pochodzenia kapłańskiego. Ezechiel w dwóch wyroczniach (Ez 34,25-30 i 37,26-28) wykracza poza pozabiblijną konwencję przymierza pokoju, dokonując równocześnie modyfikacji kapłańskiej koncepcji przymierza zawartej w Kpł 26. Księga Ezechiela, przymierze pokoju, Nowe Przymierze, Księga Kapłańska, ziemia Izraela, świątynia, pokój Obietnica jakościowo nowego przymierza, określonego mianem „przymierza pokoju” (34,25; $37,26)$, zakłada pokój ze zwierzętami, urodzajność ziemi i wybawienie od nieprzyjaciół. Jednakże istotą tego przymierza jest nie tyle ,pokój" rozumiany jako wszelkie dobro osobiste, wspólnotowe i materialne, ile obecność Boga pośród swego ludu, która stanowi jedyne źródło bezpieczeństwa, pomyślności i zbawienia. 
The motif of „covenant of peace”, as found in some Ancient Near Eastern texts, is presented Book of Ezekiel, Leviticus, in the Hebrew Bible by the Priestly tradition. covenant Ezekiel refers to the covenant of peace in two oracles: Ezek 34:35-30 and 37:26-28. He not of peace, new covenant, land only goes beyond the primeval myth but also modifies the Priestly concept as expressed in Lev 26. Ezekiel's promise of the covenant of of Israel, temple, peace peace consists of three elements: safety from wild animals, security against famine, and freedom from human enemies. However, the essence of this covenant is peace understood as God's presence amongst his people, which is the only source of the people's safety, welfare and salvation.

Idea przymierza jest fundamentalna dla rozumienia przedstawionej w Starym Testamencie relacji Boga ze swoim ludem. Wprawdzie występuje ona w różnych tradycjach biblijnych, w szczególności tych związanych z osobą Noego, Abrahama, Dawida, Lewiego i kapłaństwa lewickiego, to dla zrozumienia tożsamości biblijnego Izraela kluczowe pozostaje przymierze synajskie. Trwałość tego przymierza została zakwestionowana przez doświadczenie wygnania babilońskiego, które rodziło w sercach deportowanych do Babilonii Judejczyków wątpliwości co do osoby Jahwe jako Boga Izraela. W wypowiedziach proroków wygnania pojawia się również zapowiedź nowego przymierza, które semantycznie pozostaje w linii przymierza synajskiego (por. Jr 31,31-33; Ez 11,17-20; 36,24-28). W tym kontekście za pewne novum należy uznać pojawiającą się trzykrotnie obietnicę „przymierza pokoju”, raz u DeuteroIzajasza $(54,10)$ i dwukrotnie w Księdze Ezechiala (34,25; 37,26). Na uwagę zasługuje szczególnie prorok Ezechiel, który podejmuje się rewizji aksjomatów religii Izraela wo- 
bec kryzysu wywołanego upadkiem Jerozolimy w 586 r. przed Chr. W jakim stopniu koncepcja przymierza pokoju jest oryginalna w Księdze Ezechiela? Co stanowi treść i cel przymierza pokoju? Jaką funkcję w Księdze Ezechiela pełnią zapowiedzi przymierza pokoju, szczególnie w kontekście proroctwa o nowym przymierzu?

\section{Pytanie o możliwe źródea Ezechielowego „PRZYMIERZA POKOJU"}

Zwrot „przymierze pokoju” występuje Biblii Hebrajskiej czterokrotnie: Lb 25,12; Iz 54,10; Ez 34,25; 37,26. W przypadku tekstu z Księgi Liczb nie można mówić o przymierzu, które dotyczyłoby całego ludu wybranego. W istocie jest ono przywilejem udzielonym Pinchasowi po tym, jak zabił Izraelitów winnych odstępstwa w Baal-Peor, odwracając w ten sposób gniew Jahwe od ludu. To przymierze, będące inicjatywą Jahwe (Lb 25,12: „Oto daję jemu moje przymierze pokoju”), jest dookreślone jako „przymierze wiecznego kapłaństwa (borît kohunnat 'ôlām) dla niego i dla jego potomstwa” $(25,13)$. Pozostałe trzy wystąpienia zwrotu „przymierze pokoju" odnotowuje się w dwóch tekstach proroków wygnania babilońskiego, co świadczy o tym, że idea ta nie przynależy do wiodących elementów nie tylko przepowiadania prorockiego, ale i Biblii Hebrajskiej jako takiej.

Bernard F. Batto wykazał, że koncepcja przymierza pokoju nie jest myślą specyficznie Ezechielową ani też wyłącznie biblijną ${ }^{2}$. Wyodrębnił on motyw przymierza pokoju w staroba-

$1 \quad$ Kwestia Ezechielowych zapowiedzi przymierza pokoju została podjęta przeze mnie już wcześniej w monografii: Rola ziemi w przymierzu Boga z Izraelem, 275-282. Dokonane tam ustalenia koncentrowały się na wątku odrodzenia ziemi w przyszłym przymierzu pokoju. Zostaną one obecnie poszerzone o inne elementy stanowiące o tym przymierzu.

2 Por. Batto, „The Covenant of Peace”, 187-211. 
bilońskim micie o Atrahasisie, egipskim micie „O pokaraniu ludzkości" wchodzącym w skład Ksieggi Krowy oraz w ugaryckim cyklu o Baalu ${ }^{3}$. Wspólna dla tych tekstów jest próba zniszczenia ludzkości przez bóstwo/a, albo przez potop mający zgładzić ludzi, którzy, mimo swej użyteczności dla utrzymania systemu irygacyjnego, zakłócają odpoczynek bogom (mit o Atrahasisie), albo przez rzeź mającą położyć kres buntowi ludzi wobec bogów (mit „O pokaraniu ludzkości”; ugaryckie opowiadanie o triumfie Baala nad nieprzyjaciólmi w CTA3). Przymierze pokoju jest wynikiem zobowiązania się ze strony bóstwa, które odkłada na bok swój gniew przeciw ludziom. Harmonia między bóstwem i ludzkością objawia się w przywróceniu na ziemi rajskich warunków, których trwałość zostaje potwierdzona jakimś widzialnym znakiem ze strony bóstwa ${ }^{4}$.

Podobny schemat zdarzeń zauważa Batto w kapłańskiej relacji o przymierzu, które Jahwe zawiera z Noem po potopie (Rdz 9,8-17), jakkolwiek tam nie pojawia się wyrażenie „przymierze pokoju”. Taka wykładnia tego zdarzenia jest proponowana w Iz 54,10. W perspektywie końca wygnania Deutero-Izajasz zapowiada "przymierze pokoju” (bərît šolômî̀) - tożsame z Bożą miłością ( has dî̀), którego znakiem jest stabilność gór i pagórków. To przymierze jest wynikiem przysięgi Boga, analogicznej do tej, którą złożył Noemu $(54,9)$, przez co Boży gniew zostaje przezwyciężony przez nowy akt łaskawości Jahwe (por. 54,7-8). W ten sposób przymierze z Noem staje się „modelem i prototypem” przymierza pokoju, które w kontekście wygnania babilońskiego oznacza nową interwencję stwórczą Boga 5 .

3 Por. Batto, „The Covenant of Peace”, 192-201.

W przypadku paralelnego do Atrahasis tekstu poematu o Gilgameszu jest to naszyjnik bogini Mah, którego koraliki z lapis lazuli mają kształt much (Epos o Gilgameszu, tłum. K. Łyczkowska, tabl. IX, kol. IV, s. 55), zaś w poemacie o Baalu są to błyskawice umieszczone na niebie (CTA 3.IV.69-71; por. Pardee, „The Balu Myth”, 253, przyp. 95).

5 Borghino, La "nuova alleanza” in Is 54, 269. 
Nie można jednak twierdzić, że Ezechiel swoją koncepcję przymierza pokoju buduje na wymienionych tekstach pozabiblijnych czy też odwołuje się, jak prorok Deutero-Izajasz, do przymierza zawartego przez Boga z Noem. Ezechielowe zapowiedzi przymierza pokoju wykraczają bowiem poza nakreśloną wyżej konwencję literacką, co jest wynikiem przede wszystkim związku tych proroctw z końcowym fragmentem Kodeksu Świętości (Kpł 17-26) ${ }^{6}$. Zamykają go, zgodnie z logiką przymierza, błogosławieństwa i przekleństwa, z których te pierwsze (Kpł 26,3-13) zawierają rozliczne punkty wspólne z proroctwami o przymierzu pokoju w Ez 34,2530 i 37,26-287. Ustanie zagrożenia ze strony dzikich zwierząt w Ez 34,25 jest wyrażone identycznie jak w Kpł 26,6 (hišbattî hayy $\bar{a}^{h}-r \bar{a} \bar{a}^{-} h$ min-hāāàreș). Bezpieczne zamieszkanie (lābetahla w ziemi jest wzmiankowane w Kpł 26,5 i Ez 34,25[tu miejscem mieszkania "pustynia” i „lasy”].27.28. Informacja o braku tego, który miałby przerazić lud ('ên maḥărị̂ ), pojawia się w Kpł 26,6 i Ez 34,28. Teksty Kpł 26,13 i Ez 34,27 łączy użycie zwrotu „złamać drążek jarzma” (šā $\underline{b}$ ar $\left.m \bar{o} t \bar{t} \overline{\underline{t}} \varsigma^{\complement} \bar{o} \bar{l}\right)$ oraz terminów zbudowanych na rdzeniu ${ }^{\natural} d^{8}$. Niejasne, ze względów tekstualnych', do końca sformułowanie o udzieleniu deszczu w Ez 34,26 stanowi nawiązanie do Kpł 26,4 (gišmêkem bəcittām). O drzewach polnych rodzących owoce i ziemi wydającej swoje plony jest mowa

6 Por. Pikor, Rola ziemi w przymierzu Boga z Izraelem, 277-278.

7 Ich prezentacja w formie synopsy w: Baltzer, Ezechiel und Deuterojesaja, 156-157; Block, The Book of Ezekiel. Chapters 25-48, 304; Renaud, Nuovelle ou éternelle Alliance?, 152-153; Lyons, From Law to Prophecy, 178-180; Obinwa, „I Shall Feed Them”, 376-383; Tooman, „Covenant and Presence”, 166-169, zaś w formie opisowej w: Hossfeld, Untersuchungen zu Komposition, 274-276; Milgrom, „Leviticus 26 and Ezekiel", 58-59, 60; Hutchens, Although Yahweh Was There, 444-446.

8 Rdzeń ten pojawia się w formie rzeczownika w Kpł 26,13: mihyōt lāhem ‘ăbād̂lim („byście nie byli ich [Egipcjan] niewolnikami”), zaś w Ez 34,27 w formie czasownikowej: miyyad hā $\bar{a} \underline{o} \underline{b} \underline{d} \hat{i} m$ bāhem („z ręki zniewalających ich”).

9 Por. Pikor, Rola ziemi, 257 (przyp. 59). 
w Kpł 26,4 i Ez 34,27 ${ }^{10}$. Ez 37,26-27 nawiązuje do tekstu Kpł 26,9 (zapowiedź pomnożenia ludzi: rābāâh w Hi); 26,11a („zamieszkanie” [miškānî] Jahwe pośród ludu) i 26,12 (formuła wzajemnej przynależności). Dla części komentatorów powyższe punkty wspólne świadczyłyby, że Ezechiel lub jego uczniowie, zapowiadając przymierze pokoju (Ez 34,25-30; 37,26-28), „mieli przed oczami”"11 tekst Kpł 26 jako „swoją Vorlage"12. Inni zakładają, że dyskutowane teksty z Księgi Kapłańskiej i Ezechiela korzystałyby z tego samego źródła, co pozostaje jednak czysto hipotetycznym twierdzeniem ${ }^{13}$.

Nie wykluczając zależności Ezechielowych obietnic przymierza pokoju od Kpł 26, należy jednak podkreślić znaczące różnice między nimi, które są zauważalne m.in. w pominięciu w wyroczniach Ezechiela wzmianki o młocce, winobraniu i siewie z Kpł 26,5, braku odniesienia do miecza w Kpł 26,6 czy też opuszczenia zapowiedzi pokonania przez Izraelitów swoich wrogów z Kpł 26,7-8. Odmienność proroctwa Ezechiela leży także $\mathrm{w}$ diametralnie różnym rozumieniu przymierza: jeśli dla tradycji kapłańskiej ma ono charakter dwustronny, przez co Boże błogosławieństwo jest warunkowane wcześniejszym nawróceniem (posłuszeństwem) Izraela (por. Kpł 26,3), to w ujęciu Ezechiela jest ono jednostronną, łaskawą i bezwarunkową inicjatywą Jahwe dla swego ludu, przez co pomija się zupełnie przekleństwa sankcjonujące w Kpł 26,1415 nieposłuszeństwo Izraela. Wreszcie należy podkreślić

10 W obu miejscach powtórzone z drobnymi zmianami zwroty nātan

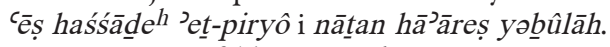

11 Ta opinia w Hossfeld, Untersuchungen zu Komposition, 276; Milgrom, „Leviticus 26 and Ezekiel”, 61.

12 Taki status przypisuje Kpł 26: Baltzer, Ezechiel und Deuterojesaja, 158; Renaud, Nuovelle ou éternelle Alliance?, 154.

13 Komentatorzy wskazują albo na teksty przeznaczone na jesienne Święto Namiotów (por. Elliger, Leviticus, 366), albo na homilię wykorzystywaną podczas liturgii celebrującej wyzwolenie Izraelitów z Egiptu (Obinwa, „I Shall Feed Them”, 381-381), albo na konwencjonalną listę błogosławieństw i przekleństw dołączaną do traktatów przymierza (por. Hals, Ezekiel, 252; Hutchens, Although Yahweh, 446). 
innowacyjne połączenie idei šālôm z koncepcją bərît, które w Kpł 26 występuje oddzielnie: „pokój” $(26,6)$ jest jednym z darów gwarantowanych „przymierzem” $(26,9)$. Tymczasem Ezechielowa koncepcja „przymierza pokoju” $(34,25 ; 37,26)$ identyfikuje borît z šālôm, wskazując tym samym na „pokój” jako treść i istotę przyszłego „przymierza”'14. Co więcej, ustanowienie tego przymierza jest zapowiedziane w obu tekstach czasownikiem kārat, a nie jak w Kpł 26,9 czasownikiem qûm w $H i$, co podkreśla, że chodzi o wydarzenie absolutnie nowe, niebędące tylko odnowieniem wcześniejszego przymierza. Przyjmując zatem, że Kodeks Świętości jest przedwygnaniową kompozycją ${ }^{15}$, pozostaje uzasadnione twierdzenie, iż zapowiadane przez Ezechiela przymierze pokoju stanowi modyfikację kapłańskiej koncepcji przymierza występującej w Kpł 26.

\section{Przymierze pokoju a Zapowiedzi nowego PRZYMIERZA W KSIĘGI EZECHIELA}

Pojawiające się w Ez 34,25 i 37,26 zapowiedzi przymierza pokoju muszą być odczytywane w kontekście Księgi Ezechiela rozumianym w dwojaki sposób: z jednej strony w związku z Ezechielowymi wypowiedziami na temat przymierza Boga z Izraelem, z drugiej strony w kontekście proroctw o odrodzeniu Izraela w Ez 34-37.

Ezechiel w pełni zasługuje na miano teologa historii. Jako pierwszy wśród proroków podejmuje się refleksji nad całością dziejów swego narodu, którą interpretuje w różnych

14 Por. Renaud, Nuovelle ou éternelle Alliance?, 162; Klein, Schriftauslegung im Ezechielbuch, 187-188.

15 Por. dyskusję nad datacją Kpł 17-26 w: Lyons, From Law to Prophecy, 29-35. Część komentatorów stoi na stanowisku, że Kpł 26, jak i cały Kodeks Świętości, jest tekstem powygnaniowym, w którym poddaje się rewizji Ezechielową koncepcję przymierza, por. Nihan, From Priestly Torah to Pentateuch, 535-545; Hieke, Levitikus, 68-70, 1065-1067. 
kluczach: metafory małżeńskiej w rozdz. 16 i 23 oraz modelu exodusu w rozdz. 20. Dla Ezechiela dotychczasowa historia przymierza, zapoczątkowanego w wyjściu z niewoli egipskiej, stanowiła ciąg powtarzających się epizodów buntu domu Izraela wobec Jahwe, których skutkiem była profanacja świętego imienia Boga (por. Ez 20,5-26). Apogeum niewierności Izraela następuje w pokoleniu Ezechiela, które doświadczając wygnania, pragnie ostatecznie odrzucić Jahwe, by jak inne narody „służyć drewnu i kamieniowi” (20,32). Taka decyzja ludu skutkuje - odkładaną dotąd przez Boga - karą (20,33; por. w. 9.14.22). W retoryce metafory małżeńskiej kara jest zgodna z prawodawstwem żydowskim, które karało cudzołóstwo śmiercią: Jerozolima - oblubienica Jahwe zostanie ogołocona (16,39), a następnie ukamienowana $(16,40)$, tak że „nie doda już zbrodni do swoich obrzydliwości” $(16,43)$. W przypadku kluczu exodusu karą jest wyprowadzenie Izraela na „pustynię ludów”, którą prorok identyfikuje jako miejsce sądu Jahwe nad swoim ludem (20,35-37).

W tym krytycznym punkcie historii Izraela, będącym udziałem pokolenia Ezechiela, prorok odkrywa prawdę o Bogu, który jest wierny przymierzu ze swoim ludem. Zostało ono „złamane” przez partnera ludzkiego (16,59), jednakże nie zostało „zapomniane” przez Boga $(16,60)$. Zywa pamięć Boga stanowi o nieodwracalności tego przymierza, które będąc „podtrzymywane” przez Niego $(16,62)$, staje się "przymierzem wiecznym” (borît ‘̂́lām w 16,60). Ta sama kwalifikacja przymierza pojawia się w 37,26, jakkolwiek zostaje ona rozszerzona o synonimiczny zwrot „przymierze pokoju" (bərît šālôm), który wcześniej wystąpił w 34,25. W obu przypadkach ustanowienie przymierza pokoju zostaje wyrażone czasownikiem kārat, który podkreśla zawarcie nowego przymierza, a nie tylko odnowienie czy podtrzymanie istniejącego wcześniej ${ }^{16}$. W perspektywie nowego przy-

16 Powyższa interpretacja bazuje na porównaniu z Ez 16,60.62, gdzie w zapowiedzi odrodzenia przymierza używa się czasownika qûm 
mierza Ezechiel zapowiada wewnętrzną przemianę ludu, która zasługuje na miano "antropologicznego przełomu”17. Nowy lud, który zamieszka w Ziemi Obiecanej, nie będzie bowiem wynikiem tylko negatywnej selekcji mającej nastąpić w trakcie nowego exodusu (por. 20,37-38). Wobec niezdolności Izraela do „uczynienia sobie nowego serca i nowego ducha" (por. 18,31), bez których niemożliwe jest trwanie we wspólnocie przymierza z Jahwe, inicjatywę przejmuje Bóg, zapowiadając wewnętrzne odnowienie partnera swego przymierza $(36,24-28)$. Dar nowego serca i nowego ducha (w. 26-27a) każe postrzegać to odrodzenie w kategoriach nowego stworzenia, na które składają się jeszcze dwa elementy paralelne względem siebie: oczyszczenie z grzechów (w. 25) i uzdolnienie do zachowywania Prawa (w. 27b). Bez tego aktu nowego stworzenia ludu nie będzie możliwy nie tylko jego powrót do Ziemi Obiecanej, ale również jego zamieszkanie na stałe w odrodzonej ziemi. To nowe przymierze, mimo że jest opisane konwencjonalną formułą wzajemnej przynależności (por. w. 28), opiera się na nowym fundamencie, którym jest najpierw przebaczenie wprowadzające Izrael w sferę świętości Boga, następnie samoudzielenie się Jahwe w swoim duchu, który ożywia Izrael, i wreszcie uzdolnienie ludu do zachowywania Prawa.

Nowość przymierza zapowiadanego w Księdze Ezechiela objawia się ostatecznie w obietnicy przymierza pokoju, które pojawia się w 34,25 i 37,26. Proroctwa o przymierzu pokoju przynależą do dwóch większych wyroczni: pierwsze (34,2531) zamyka słowa skierowane przeciwko obcym pasterzom w rozdz. 34, drugie $(37,26-28)$ przynosi zwieńczenie słowa wyjaśniającego czynność połączenia dwóch kawałków drewna jako zapowiedź zjednoczenia ziemi Izraela i Judy pod jed-

w Hi. Podobne rozróżnienie między znaczeniem użycia czasownika kāraț i qûm w Hi w związku z borît w: Greenberg, Ezekiel 1-20, 291; Renz, The Rhetorical Function, 167; Renaud, Nuovelle ou éternelle Alliance?, 131.

17 Sedlmeier, „Transformationen”, 231. 
nym władcą (37,15-28). Opowiadanie o czynności połączenia dwóch kawałków drewna zawiera - szczególnie w słowie objaśniającym akcję proroka (w. 21-28) - wiele odniesień leksykalnych i tematycznych do wyroczni skierowanej do pasterzy Izraela w rozdz. 34. W obu tekstach pada ze strony Boga zapowiedź „Dawida, mojego sługi” (34,23.24; 37,24.25), który będzie panował jako ,jeden pasterz” (34,23; 37,24). Jest on określony mianem „władcy” (nāsî̀̃) w 34,24 i 37,24. Jego panowanie będzie się rozciągać nad ludem, który zostaje zebrany i przyprowadzony do "swojej ziemi” ( 'ad utożsamionej z „górami Izraela” (34,13; 37,21.22). W kontekście władzy nowego Dawida Jahwe zapowiada zawarcie „przymierza pokoju” (borît šālôm w 34,25; 37,26). W 37,26 przymierze pokoju zostaje dookreślone jako „przymierze wieczne" (borît ‘̂́lām). Termin 'ôlām kwalifikuje w tym kontekście nie tylko przymierze, ale również zamieszkanie Izraela w swojej ziemi $(37,25)$, panowanie Dawida $(37,25)$ i przebywanie pośród nich przybytku (miqdāšši 37,26.28). Te nawiązania narracji o połączeniu dwóch kawałków drewna z towarzyszącym mu wyjaśnieniem $(37,15-28)$ do wyroczni z rozdz. 34 pozwalają postrzegać oba teksty jako rodzaj obramowania sekwencji Ez 34-37. Zarazem tekst 37,15-28 podkreśla ostateczność i nieodwracalność czynionych w tej części Ezechiela zapowiedzi odrodzenia, co zostaje wyartykułowane nagromadzeniem w finalnych wersetach rozdz. 37 rzeczownika 'ôlām, który dosłownie stanowi ostatnie słowo całej sekwencji rozdz. 34-37.

\section{Struktura Retoryczna Ezechielowych PROROCTW O PRZYMIERZU POKOJU}

Obecność w Księdze Ezechiela dwóch wyroczni zapowiadających przymierze pokoju - 34,25-30 i 37,26-28 - jest przykładem „ekspozycji przejmującej”, która stanowi rodzaj egzegezy wewnątrzbiblijnej: pewne motywy wprowadzone 
wcześniej zostają na podjęte i rozwinięte w nowych kontekstach Księgi Ezechiela ${ }^{18}$. Z tego powodu należy zweryfikować strukturę retoryczną tych dwóch proroctw, by ustalić zachodzące między nimi relacje formalne i treściowe.

\subsection{Dynamika wyroczni Ez 34,25-30}

Proroctwo przeciwko pasterzom Izraela w rozdz. 34 zawiera wiele formut formalnych pozwalających na wyodrębnienie w nim mniejszych jednostek retorycznych. Uwzględniając adresatów proroctwa, można je podzielić na dwa fragmenty: w. 2-16 - słowo skierowane do pasterzy Izraela; w. 17-31 - słowo adresowane do owiec Izraela. Od strony treściowej zauważa się, że w drugim fragmencie temat pasterzy i owiec jest nieobecny w w. 25-30, które przynoszą zapowiedź przymierza pokoju. Odrębność tej części znajduje potwierdzenie formalne przez obecność w w. 24 typowej dla Ezechiela formuły autointrodukcyjnej "Ja, Jahwe, powiedziałem"19, pełniącej funkcję konkluzyjną dla jednostki zapoczątkowanej formułą posłańca w w. 17, podejmującej temat jednego pasterza Dawidowego nad Izraelem. Granicę jednostki w w. 30 wyznacza formuła poznania Jahwe, po której występuje formuła konkluzyjna „wyrocznia Pana Jahwe”. W w. 31 następuje ponowne bezpośrednie zwrócenie się do „owiec", wobec których Bóg potwierdza formułą wzajemnej przynależności swoje przymierze z nimi, zamykając tym samym (również przez formułę konkluzyjną „wyrocznia Pana Jahwe”) całą wyrocznię.

Dla ukazania dynamiki retorycznej proroctwa o przymierzu pokoju zostanie przywołany jego tekst z zaznaczeniem elementów znaczących retorycznie:

18 Szerzej o tym fenomenie Księgi Ezechiela w: Pikor, Rola ziemi, 87-92.

19 Określenie tej formuły za: Block, The Book of Ezekiel. Chapters 1-24, 36-37. 
${ }^{25}$ I zawrę z nimi przymierze pokoju

i usunę złe zwierzęta z ziemi,

i zamieszkają na pustyni bezpiecznie,

i będą spać w lasach.

${ }^{26}$ I udzielę im i terenom wokół mojego wzgórza błogosławieństwa

i spuszczę deszcze w jego czasie i deszcze błogosławieństwa będą.

${ }^{27}$ I wydadzą drzewa polne swoje owoce

i ziemia wyda swoje plony,

i będą w swojej ziemi bezpieczni,

I POZNAJĄ, ŻE JA JESTEM JAHWE, gdy złamię drążki ich jarzma

i wyzwolę ich z ręki trzymających ich w niewoli.

${ }^{28}$ I nie będą więcej łupem dla narodów,

i zwierzęta ziemi nie będą pożerały ich,

i zamieszkają bezpiecznie,

i nikt ich nie przerazi.

${ }^{29}$ Ustanowię im wspaniałą plantację ${ }^{20}$

i nie będą więcej niszczeni głodem w ziemi,

i nie będą więcej znosić szyderstwa narodów.

${ }^{30}$ I POZNAJĄ, ŻE JA, JAHWE, ich Bóg, jestem z nimi,

a oni są moim ludem, dom Izraela, wyrocznia Pana Jahwe.

Obecność formuły poznania Jahwe w w. 27d i w. 30a w pozycji konkluzyjnej pozwala wyodrębnić w wyroczni dwa

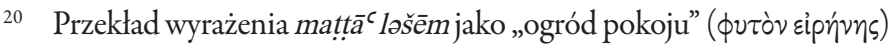
w LXX, podobnie jak w wersji syryjskiej i Targumie, zakłada w TM metatezę (takie rozwiązanie proponowane przez redaktora BHS). Jednakże konstrukcja lošēm pojawia się w innych miejscach Biblii Hebrajskiej jako synonim lithilla $\bar{a}^{h}$ i loti $\bar{p}^{2}$ eret (por. Pwt 26,19; Jr 13,11) co przemawia za rozumieniem wspomnianej w Ez 34,29 „plantacji” jako „wspaniałej”, to znaczy przynoszącej sławę domowi Izraela i rodzącej w nim dumę. Desygnatem rzeczownika matța ${ }^{c}$ może być zarówno drzewo owocowe (por. winorośl w 17,7), jak i każde inne drzewo rosnące w lasach czy na polu (por. „drzewa polne" w 31,4). 
urywki: w. 25a-28a i w. 28b-29c. Mimo braku formalnych powtórzeń, należy uznać w. 25a i w. 30 za obramowujące proroctwo: w. 25a jako wprowadzający temat przymierza pokoju, zaś w. 30 zamykający go formułą przymierza.

Dwa urywki składające się na wyrocznię pozostają względem siebie paralelne, za czym przemawia powtórzenie pewnych terminów stanowiących o tematyce poszczególnych członów dwóch urywków ${ }^{21}$. Przyszłe „bezpieczne zamieszkanie" ludu w Ziemi Obiecanej, gwarantowane usunięciem niebezpieczeństwa ze strony dzikich „zwierząt”, stanowi o paralelnej pozycji w. 25b-d i w. 28b-d. Wspólny temat przyszłego urodzaju w Ziemi Obiecanej, budowany przez powtórzenie terminu „ziemia” w znaczeniu gleby oraz wyrażeń „drzewa polne” $\mathrm{i}$ „wspaniała plantacja” odnoszących się do drzew owocowych, wiąże w. 26-27c i w. 29ab. Wreszcie przywołanie „narodów” jako źródła zagrożenia dla Izraela łączy w. 27d-28a i w. 29c.

Uwzględniając paralelizm zachodzący wewnątrz wyroczni, można zaproponować następujący schemat jej struktury, w której paralelne człony zawierają kolejne elementy charakteryzujące przymierze pokoju:

Nagłówek: wprowadzenie tematu przymierza pokoju (w. 25a) A usunięcie dzikich zwierząt (w. 25b-d)

B urodzajność ziemi (w. 26-27c)

C wybawienie od nieprzyjaciół (w. 27d-28a)

A' usunięcie dzikich zwierząt (w. 28b-d)

B' urodzajność ziemi (w. 29a-b)

C' wybawienie od nieprzyjaciół (w. 29c)

Konkluzja: formuła przymierza (w. 30)

21 Por. Hossfeld, Untersuchungen zu Komposition, 276; Allen, Ezekiel 20-48, 160-161; Block, The Book of Ezekiel. Chapters 25-48, 305; Sedlmeier, „Ich schließe”, 49-50; Klein, Schriftauslegung im Ezechielbuch, 172. 


\subsection{Dynamika wyroczni Ez 37,26-28}

Druga zapowiedź przymierza pokoju w Ez 37,26 przynależy formalnie do narracji o ostatniej z czynności znaczeniowych wykonanych przez Ezechiela: jest nią połączenie dwóch kawałków drewna symbolizujących Izrael i Judę, które na powrót staną się jednym ludem Boga. Formalnie opowiadanie to zawiera się w tekście 37,15-20, w którym znajdują się wszystkie elementy charakterystyczne dla tego rodzaju narracji: polecenie wykonania czynności (w. 16-17), prośba świadków czynności o podanie jej znaczenia (w. 18), interpretacja czynności (w. 19-20). Wyrocznia zawarta w w. 21-28 przynosi dalsze wyjaśnienie tej akcji. Mając na uwadze powtórzenia terminów określających jednego przyszłego władcę nad zjednoczonym ludem: melek w w. 22[x2].24 i nāŝî̉ w w. 25, zasadne jest wyróżnienie w niej dwóch części: (1) w. 24-25: zamieszkanie w Ziemi Obiecanej jednego narodu rządzonego przez jednego z potomków Dawida; (2) w. 26-28: przymierze pokoju.

Część komentatorów proponuje inną delimitację tych dwóch części, sugerując się powtórzeniami liczebnika 'eḥād (,jeden”) w w. 22[x2] i w. 24a: w. 21-24a i w. 24b-28 22 . Problematyczność takiej strukturyzacji bierze się z faktu, że powtórzenie zwrotu "Dawid, mój sługa” na początku w. 24 (z dookreśleniem go tytułem melek ) i na końcu w. 25 (z dopowiedzeniem tytułu nāsî́? ) służy za inkluzję wydzielającą w. 24-25 jako jednostkę retoryczną. W rezultacie przyszłe panowanie potomka Dawidowego nie przynależy do charakterystyki przymierza pokoju.

Tekst drugiego proroctwa z zaznaczeniem elementów znaczących retorycznie jest następujący:

${ }^{26}$ I zawrę z nimi przymierze pokoju, przymierze wieczne będzie z nimi.

22 Tak m.in. Block, The Book of Ezekiel. Chapters 25-48, 408-409; Allen, Ezekiel 20-48, 192, Sedlmeier, „Ich schließe”, 60. 
I dam im ${ }^{23}$, i pomnożę ich,

i dam przybytek pośród nich NA ZAWSZE.

${ }^{27}$ Moje zamieszkanie będzie nad nimi,

$i$ będę dla nich Bogiem, a oni będą mi ludem.

${ }^{28}$ I poznają narody, że Ja, Jahwe, uświęcający Izrael,

gdy będzie mój przybytek pośrodku nich NA ZAwSZE.

Pozycję terminu końcowego zajmuje zdanie „przybytek pośród nich na zawsze" (w. 26d.28b), przez co zasadne jest wyróżnienie dwóch urywków. Mimo że brak między nimi formalnych powtórzeń, można mówić o paralelizmie między nimi. Zauważa się bowiem, że formule wzajemnej przynależności z w. 27b odpowiada dwukrotne wzmiankowanie terminu „przymierze” w w. 26ab. Schematycznie strukturę paralelną omawianego urywku można oddać następująco:

A przymierze pokoju jako przymierze wieczne (w. 26ab)

$\mathrm{B}$ lud w darowanej ziemi przestrzenią dla przybytku Jahwe (w. 26cd)

A' formuła wzajemnej przynależności potwierdzająca status Izraela (w. 27ab)

B' lud uświęcony przez Jahwe przestrzenią dla przybytku Jahwe (w. 28)

Rozszerzenie charakterystyki przymierza pokoju zapowiedzianego już w rozdz. 34 następuje przez dwa elementy. Pierwszym jest kwalifikacja przymierza jako „przymierza wiecznego" (37,26b), przy czym termin ‘̂̀lām zajmuje pozycję inkluzyjną w tej wyroczni (por. 37,28b) ${ }^{24}$. Podkreślenie

23 Problem interpretacyjny stanowi sformułowanie ûnotattîm w w. 26c. Przy założeniu, że końcowe mem stanowi dativus commodi, możliwe jest interpretowanie go jako skróconej formuły darowania ziemi: „dam im [ziemię Izraela]” (por. Block, The Book of Ezekiel. Chapters 25-48, 419).

24 Uwzględniając strukturę paralelną trzech wersetów składających się na Ez 37,26-28, wynikającą z powtórzenia motywu Bożej obecności 
wiecznego trwania przymierza pokoju akcentuje nie tyle nieograniczone czasowo trwanie tej relacji (w istocie każde przymierze było zawierane na czas nieokreślony), ile raczej kładzie nacisk na jego definitywny i nieodwołalny charakter. Gwarantuje to drugi element pogłębiający rozumienie przymierza pokoju w Ez 37,26-28: obecność Boga pośród swego ludu, co zostaje powtórzone w każdym z trzech wersetów składających się na tę wyrocznię w. 26d.27a.29b.

\section{Charakterystyka przymierza pokoju}

Kwalifikacja przymierza zapowiadanego w Ez 34,25 i 37,26 rzeczownikiem šâlôm wymaga odpowiedzi na pytanie o fundament, a zarazem istotę przymierza pokoju. Sam termin šālôm obejmuje szeroki wachlarz znaczeń, które są wyprowadzone $\mathrm{z}$ jego podstawowego sensu jako „pełność, nienaruszoność": dobrobyt, sukces, pomyślność, bezpieczeństwo, pokój (jako brak wojny), przyjaźń, ocalenie, zbawienie ${ }^{25}$. Polisemantyczny rzeczownik šālôm obejmuje zatem to wszystko, co zwiera słowo „dobro” w odniesieniu do różnych podmiotów: (1) dobro osobiste, którym może być zdrowie, długie życie, wybawienie z niebezpieczeństwa, pomyślność i dobrobyt; (2) dobro wspólnotowe doświadczane jako harmonia i ład w życiu politycznym i społecznym, zarówno wewnątrz wspólnoty, jak i wobec czynników zewnętrznych; (3) dobro ziemi objawiające się w jej żyzności i bogactwach

pośród Izraela („przybytek”, ,zamieszkanie”), zauważa się odwrócenie kolejności członków składających się na formułę wzajemnej przynależności w w. 27. Jeśli normalnie zakłada się w niej układ: Izrael jako lud Boga - Jahwe jako ich Bóg, to tu następuje odwrotna kolejność, w rezultacie czego w. 27 zamyka zwrot lî $10^{c} \bar{a} m$, budując tym samym paralelizm asonansowy z 'ôlām zamykającym w. 26.28.

25 Powyższe zestawienie znaczeń terminu šālôm za: HALAT II, 1418-1424. Por. syntetycznie przedstawioną dyskusję nad sensem

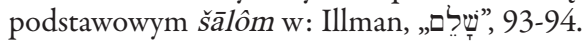


naturalnych ${ }^{26}$. Tak różnorodna treść słowa šālôm czyni je jednym z podstawowych terminów używanych przez proroków w opisach przyszłego zbawienia mesjańskiego (por. Iz 9,5-6; 53,5; Mi 5,4; Za 9,10) i eschatologicznego (por. Iz 45,$7 ; 52,7 ; 57,19 ; 60,17 ; 66,12 ;$ Jr 29,7.11; 33,6.9). W tym kontekście należy też sytuować zapowiedzi przymierza pokoju w Księdze Ezechiela.

\subsection{Usunięcie dzikich zwierząt}

Ezechiel zalicza dzikie zwierzęta do jednego z czterech narzędzi Bożego sądu nie tylko nad swoim ludem, ale również nad innymi narodami (por. Ez 5,17; 14,15.21; 33,27) ${ }^{27}$. W tym przekonaniu Ezechiel pozostaje zgodny z tekstem Kpł 26,22, który wśród przekleństw spadających na lud za złamanie przymierza wymienia dzikie zwierzęta. Podobne postrzeganie zagrożenia ze strony dzikich zwierząt występuje również u innych proroków (por. Jr 5,6). Z lęku przed dzikimi zwierzętami unikało się niekiedy wychodzenia z domu czy podróżowania nocą (por. Ps 104,20-22; Prz 22,13). W kontekście przymierza z Noem dzikie zwierzęta mogą być też postrzegane jako symbol chaosu zagrażającego ludzkiemu życiu (por. Rdz 9,2) ${ }^{28}$. Wraz z usunięciem dzikich zwierząt zniknie strach przed grożącym $\mathrm{z}$ ich strony niebezpieczeństwem (Ez 34,28d). W rezultacie, „pustynia” i „lasy”, będące dotąd naturalnym siedliskiem dzikich zwierząt, staną się miejscem zamieszkania ludzi $(34,25 \mathrm{~cd})$. W tym wypadku „pustynia” i „las” tworzą meryzm opisujący całość świata, od terenów pozbawionych roślinności po obszary gęsto zalesione ${ }^{29}$. Cały zatem świat będzie przestrzenią pokoju gwarantującego „bezpieczną” egzystencję człowieka (34,25c.28c).

26 Por. Renaud, Nuovelle ou éternelle Alliance?, 170.

27 Pozostałe trzy to: miecz [w sensie nieprzyjaciół zadających śmierć mieczem], głód i zaraza.

28 Por. Sedlmeier, „Ich schließe”, 51.

29 Por. Block, The Book of Ezekiel. Chapters 25-48, 305. 
Inaczej niż w Oz 2,20, gdzie zwierzęta są partnerami przymierza z Bogiem, będąc tym samym podporządkowane Jego władzy, w Ez 34,25 zapowiadany jest pokój nie tyle dla zwierząt, co raczej od zwierząt, dzięki czemu Izrael będzie mógł mieszkać bezpiecznie w swojej ziemi.

Część komentatorów proponuje alegoryczne rozumienie „dzikich zwierzętach” - jako obcych narodów w Ezechielowych zapowiedziach przymierza pokoju. Powołują się na wcześniejsze dwukrotne oskarżenie pasterzy, że z powodu ich obojętności owce „stały się żerem wszelkiego dzikiego zwierza" $(34,5.8)^{30}$. Moshe Greenberg zauważa jednak, że w przynajmniej w 34,28 prorok rozróżnia między zagrożeniem ze strony dzikich zwierząt i obcych narodów, co kore-

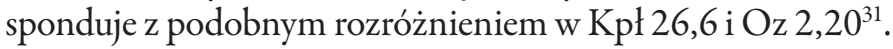

\subsection{Urodzajność ziemi}

Drugim aspektem przymierza pokoju jest odrodzenie ziemi Izraela. Ta, pozostając dotąd "pustynią" i „lasem” (34,25cd), zostanie przekształcona przez „deszcz błogosławieństwa”, który przyniesie płodność i żyzność naturze (34,26-27c). W rezultacie ustanie głód - narzędzie karzącego działania Jahwe $(34,29 a-b)^{32}$.

Głód jako jeden z Bożych agentów śmierci (por. Ez 6,11.12; $7,15 ; 14,13)$ jest na pierwszym miejscu rezultatem braku opadów deszczu, które zależą wyłącznie od Boga. Podstawowym źródłem odrodzenia ziemi Izraela jest deszcz zsyłany przez Jahwe, który w 34,26 jest przedstawiony jako przejaw Bożego błogosławieństwa. Wspomniane tam „deszcze błogosławieństwa” to deszcze udzielane przez Boga „w ich czasie”. Jr 5,24 doprecyzowuje ten „ich czas” jako „deszcz wczesny” (gešem

30 Tak np. Obinwa, „I Shall Feed Them”, 390.

31 Greenberg, Ezekiel 21-37, 702-703.

32 Głód jako narzędzie Bożej kary jest przedstawiany w Ez 5,12.16-17; 6,11-12; 7,15; 12,16; 14,13.21. 
yôre $\left.{ }^{h}\right)$, przypadający w Palestynie na okres od końca października do początków grudnia, oraz jako „deszcz późny” (malqôs̆), występujący w marcu i kwietniu. Specyficzna sytuacja hydrologiczna (brak większych rzek, których wylewy pozwalałyby na nawadnianie ziemi) i geoklimatyczna Palestyny (wyższe opady w regionie nadmorskim i na terenie górskim, przy równoczesnym wyparowaniu ok. 60-70\% wody deszczowej i nierównomiernym rozkładzie dni deszczowych) powodowała, że deszcz (również rosa) był prawdziwym znakiem Bożego błogosławieństwa dla ziemi ${ }^{33}$. Dzięki tym opadom „drzewa polne wydadzą swoje owoce i ziemia wyda swoje plony" (Ez 34,27). Bóg nie tylko udziela ziemi deszczu niezbędnego dla życia wegetacyjnego, ale również jest źródłem jej żyzności i urodzaju. To Jahwe „przywołuje zboże i pomnaża je" $(36,29)$. Użyty w tym zdaniu czasownik $q \bar{a} r \vec{a}$ pojawia się również w Biblii Hebrajskiej w syntagmie „przywołać głód”, który jest spowodowany brakiem opadów (por. $2 \mathrm{Krl}$ 8,1; Ps 105,16). Zapowiadając odrodzenie ziemi Izraela, Jahwe mówi o sobie wręcz jako rolniku, który „obsadza (nāta $\left.{ }^{\complement} \hat{i}\right)$ to, co spustoszone” (36,36). Podobny obraz znajduje się w 34,29, kiedy Jahwe zapowiada „ustanowienie wspaniałej plantacji (matța $\left.\bar{c}^{\complement} l o s ̌ e \bar{m}\right)$ " dla swojego ludu w ziemi Izraela. Jej wspaniałość jest pewnie pochodną imponujących rozmiarów i obfitości Bożej uprawy. Jednakże czasownik năța w tych dwóch metaforycznych opisach działania Boga wobec ziemi podkreśla również permanencję tych upraw ${ }^{34}$, dzięki czemu mieszkańcy ziemi Izraela nie będę musieli więcej doświadczać głodu, który wcześniej wywoływał szyderstwa ze strony obcych narodów (por. 34,29; 36,30).

33 Szczegółowa analiza warunków hydrologicznych i geoklimatycznych Palestyny w: Pikor, Soteriologiczna metafora, 58-61.

34 Por. Greenberg, Ezekiel 21-37, 704. 


\subsection{Wybawienie od nieprzyjaciół}

Trzecim wyznacznikiem przymierza pokoju jest uwolnienie Izraela od nieprzyjaciół. W pierwszym rzędzie chodzi o wyzwolenie z rzeczywistej niewoli, o czym jest mowa w w. 27de. Zewnętrznym znakiem zniewolenia jest jarzmo, które zostanie złamane ${ }^{35}$. Identyczna zapowiedź pojawia się w Kpł 26,13. Zniewalające Izraelitów jarzmo zostało im nałożone przez króla babilońskiego, który uprowadził ich w niewolę. W ziemi wygnania lud Jahwe został zaprzęgnięty do niewolniczej pracy. Konstrukcja ${ }^{a} \underline{a} \underline{b} a \underline{d}+b o+$ sufiks sugeruje, że praca Izraelitów miała charakter przymusowy, wymuszana była przemocą ze strony Babilończyków. Przyimek bo może być interpretowany jako narzędziowy ${ }^{36}$ - wówczas chodziłoby o pracę, którą Babilończycy wykonują, posługując się deportowanymi Żydami. Możliwa jest również interpretacja adwersatywna, według której przyimek bo wskazywałby na władzę obcych narodów nad podbitymi Izraelitami, sprawowaną za pomocą przemocy i ucisku ${ }^{37}$. Izraelici doświadczyli już wcześniej w swojej historii podobnego zniewolenia, kiedy potomkowie Jakuba znaleźli się w Egipcie. Praca przy wyrabianiu cegły, potrzebnej do budowli faraona, była im

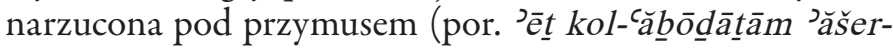

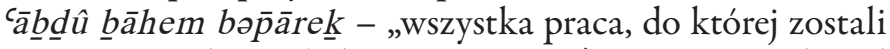
przymuszeni bezwględnie” w Wj 1,14). Tam Bóg „złamał drążek ich jarzma” i „wyprowadził ich z ziemi egipskiej, by nie byli niewolnikami" (Kpł 26,13). Obecnie uczyni to samo wobec swego ludu przebywającego w Babilonii ${ }^{38}$.

- „drążek jarzma”. Częściej pojawia się konstrukcja, w której dopełnieniem bliższym czasownika „złamać” (šābar) jest sam rzeczownik môtăh $\bar{a}^{h}$ ôtôt), por. Jr 28,10.12.13; Ez 30,18.

36 Por. Greenberg, Ezekiel 21-37, 703.

37 Por. GKC \$119k.

38 Podobna myśl jak w Ez 34,27 znajduje się w Jr 30,8, gdzie Bóg mówi o „złamaniu jarzma ( $\breve{a} \underline{b}$ bar ‘ $\bar{O} I)$ na karku” swego ludu przebywające- 
Wraz z wyzwoleniem swego ludu Bóg zatroszczy się o to, by „już więcej nie znosił szyderstwa narodów” (Ez 34,29c), co dopełnia obietnicę z 34,28a, że „więcej nie będą łupem dla narodów”. Zwrot kolimmat haggôyīm („szyderstwa narodów") staje się zrozumiały, gdy uwzględni się jego wystąpienie w 36,15. W zdaniu kończącym wyrocznię przeciwko obcym narodom (35,1-15) Pan Bóg zapowiada, że ziemia Izraela „nie będzie więcej słuchać szyderstwa narodów”. Słowa obcych narodów są cytowane w 36,2: „Ha, odwieczne wyżyny stały się posiadłością dla nas” - roszczą sobie one zatem pretensję do ziemi Izraela, naruszając tym samym własność Jahwe. Traktują tę ziemię jako łup, ogołacając ją ze „srebra i złota, trzody i dobytku” (por. opis plądrowania ziemi Izraela przez Goga w 38,13), pustosząc jej pastwiska (por. zwrot loma ${ }^{c} a n$ miḡ $r a \bar{a} s \bar{a} h$ lābazaz $36,5^{39}$ ). Odrodzona ziemia Izraela stanie się na powrót „dziedzictwem” Izraela, który „weźmie ją w posiadanie” $(36,12)$.

\section{OBECNOŚĆ JAHWE - ŹRÓDłO PRZYMIERZA POKOJU}

Przy tak złożonej charakterystyce przymierza pokoju w Ez 34,25-30 i 37,26-28, pozostaje wciąż pytanie o fundament, a zarazem istotę tego przymierza. Ten element musi być szukany w tym, co łączy oba proroctwa. Jest nim bez wątpienia formuła wzajemnej przynależności, która pojawia się w 34,30 i 37,27. Dochodzi tym samym jeszcze jeden element charakteryzujący przymierze pokoju: osobowa relacja Jahwe ze swoim ludem.

go w Babilonii i w konsekwencji o tym, że „obcy już więcej ich nie zniewolą ( ‘āba $\underline{\underline{d}}+$ + bə)”; por. Obinwa, „I Shall Feed Them”, 402-403.

39 Przyjęta tu interpretacja rzeczownikowa terminu miḡrāāāăh zakłada jego znaczenie analogiczne do rzeczownika miḡrrāš, oznaczającego w Ez 45,2; 48,15.17 tereny przylegające do miasta, pastwiska (por. Lb 35,2; Kpł 25,34 itd.). Por. Pikor, Rola ziemi, 104, przyp. 24. 
Interpretacja tej formuly w 34,30 wymaga uwzględnienia paralelnych zdań wprowadzonych formułą poznania w w. 27.30. Jahwe daje się poznać najpierw przez wyzwolenie swojego ludu z jarzma zniewolenia i ucisku (w. 27de). $\mathrm{W}$ ten sposób Izraelici nie są więcej podporządkowani obcym narodom i mogą, już jako wolni, uczestniczyć w relacji przymierza z Jahwe jako „Jego lud”. Tę myśl wyraża formuła wzajemnej przynależności w w. 30, która jednak odbiega od konwencjonalnego ujęcia: "Ja będę ich Bogiem, a oni będą moim ludem". Z jednej strony obaj partnerzy zostają dookreśleni odpowiednio jako "Jahwe" i „dom Izraela”, co podkreśla nowy status Izraela, który nie jest już więcej „domem zbuntowanym" ${ }^{\prime \prime 4}$, lecz ludem wybranym, co koresponduje z celem zakładanym przez pierwsze przymierze (por. Ez 20,5). $\mathrm{Z}$ drugiej strony pierwszy człon formuly przymierza zostaje rozszerzony o formułę asystencji: „Ja ( 'ănî), Jahwe, ich Bóg, jestem z nimi ('ittām)". Modyfikuje ona w istotny sposób formułę wzajemnej przynależności, przesuwając akcent na zaangażowanie się Boga w relację ze swoim ludem. Obecność Boga staje się dla Izraela źródłem ochrony i wsparcia, pomyślności i zbawienia. Tym samym šālôm wpisany w to nowe przymierze konkretyzuje się w obecności Jahwe pośród swego ludu.

Formuła wzajemnej przynależności leży w samym centrum wyroczni Ez 37,26-28. W każdym z trzech wersetów tego proroctwa Bóg zapowiada swoją obecność w Izraelu w postaci materialnego znaku świątyni (miqdāšî w w. 26.28; miškānî $\mathrm{w} w$. 27). Ten zabieg retoryczny sprawia, że przymierze pokoju (w. 26) objawia się jako wspólnota przymierza (w. 27), poprzez którą Jahwe uświęca Izrael (w. 28). Jeśli wcześniej Bóg pragnął uświęcić swój lud (məqaddəšām) poprzez instytucję szabatu $(20,12)$, tak teraz sam staje się źródłem uświęcenia Izraela (moqaddēš ’et-yiśrā’ēt), właśnie przez swoją obecność pośród ludu $(20,28)$. Nie chodzi tylko o uświęcenie się 
Jahwe poprzez swój lud ( $q a \bar{a} \underline{d} a s ̌ \mathrm{w} N i+b \partial$ ), który zostanie zgromadzony i wprowadzony na nowo do Ziemi Obiecanej (por. 20,41; 28,25; 36,23; 39,27), lecz o włączenie ludu w sferę świętości samego Boga i przekształcenie go w żywe świadectwo świętości Boga wobec świata. W perspektywie przymierza pokoju zapowiadanego w 37,26-28 brak jakiegokolwiek odniesienia do materialnej lokalizacji sanktuarium Boga. Jest ono sytuowane w wymiarze osobowej relacji Boga ze swoim ludem ${ }^{41}$, która będzie się realizować w odrodzonej ziemi. W ten sposób Ziemia Obiecana będzie miejscem „zamieszkania” nie tylko Izraela (por. yāšb̆û w 34,25), ale i samego Jahwe (por. mišskānî w 37,27), którego trwała i definitywna obecność pośród swego ludu będzie źródłem, istotą i gwarancją wiecznego przymierza pokoju.

\section{ZAKOŃCZENIE}

Idea przymierza pokoju, występująca w tekstach starożytnego Bliskiego Wschodu, w Biblii Hebrajskiej pojawia się w tekstach pochodzenia kapłańskiego. Ezechiel w dwóch wyroczniach (Ez 34,25-30 i 37,26-28) wykracza poza pozabiblijną konwencję przymierza pokoju, dokonując równocześnie modyfikacji kapłańskiej koncepcji przymierza zawartej w Kpł 26. Obietnica jakościowo nowego przymierza, określonego mianem „przymierza pokoju” $(34,25 ; 37,26)$, zakłada pokój ze zwierzętami, urodzajność ziemi i wybawienie od nieprzyjaciól. Jednakże istotą tego przymierza jest nie tyle „pokój” rozumiany jako wszelkie dobro osobiste, wspólnotowe i materialne, lecz obecność Boga pośród swego ludu, która stanowi jedyne źródło bezpieczeństwa, pomyślności i zbawienia.

41 Por. Greenberg, Ezekiel 21-37, 758; Klein, Schriftauslegung im Ezechielbuch, 191. 
Allen L.C., Ezekiel 20-48 (Word Biblical Commentary 29; Dallas, TX: Word Books 1994).

Baltzer, D., Ezechiel und Deuterojesaja. Berührungen in der Heilserwartung der beiden großen Exilspropheten (BZAW 121; Berlin - New York: De Gruyter 1971).

Batto, B.F. „The Covenant of Peace. A Neglected Ancient Near Eastern Motif", Journal of Biblical Literature 49 (1987) 187-211. Begg, C.T., "Berit in Ezekiel”, Proceedings of the Ninth World Congress of Jewish Studies. Division A. The Period of the Bible (red. D. Assaf) (Jerusalem: World Union of Jewish Studies 1986) 77-84.

Block, D.I., The Book of Ezekiel. Chapters 1-24 (NICOT; Grand Rapids, MI - Cambridge: Eerdmans 1997).

Block, D.I., The Book of Ezekiel. Chapters 25-48 (NICOT; Grand Rapids, MI - Cambridge: Eerdmans 1998).

Borghino, A., La "nuova alleanza” in Is 54. Analisi esegetico-teologica (Tesi Gregoriana. Serie Teologia 118; Roma: Gregorian \& Biblical Press 2005).

Eichrodt, W., Ezekiel. A Commentary (OTL; London: Westminster John Knox ${ }^{5}$ 1996; oryg. niem. 1965).

Elliger, K., Leviticus (HAT 4; Tübingen: Mohr Siebeck 1966). Eposo Gilgameszu, tłum. K. Łyczkowska (Warszawa: AGADE 2002). Gesenius, W. - Kautzsch, E. - Cowley, A.E., Gesenius' Hebrew

Grammar (Oxford: Oxford University Press $\left.{ }^{2} 1910\right)$ (=GKC). Greenberg, M., Ezekiel 1-20. A New Translation with Introduction and Commentary (AB 22; New York - London - Toronto Sydney - Auckland: Doubleday 1983).

Greenberg, M., Ezekiel 21-37. A New Translation with Introduction and Commentary (AB 22A; New York - London - Toronto - Sydney - Auckland: Doubleday 1997).

Hieke, T., Leviticus. Erster Teilband: 1-15 (HThKAT, Freiburg - Basel - Wien: Herder 2014).

Hossfeld, F., Untersuchungen zu Komposition und Theologie des Ezechielbuches (FzB 20; Würzburg: Echter 1977). 
Hurvitz, A., A Linguistic Study of Relationship between the Priestly Source and the Book of Ezekiel. A New Approach to an Old Problem (CRB 20; Paris: Gabalda 1982).

Hutchens, K.D., Although Yahweh Was There. The Land in the Book of Ezekiel (Dissertation Emory University; Atlanta, GA 1998). Illman, K.-J., „שָָׁ", Theologisches Wörterbuch zum Alten Testament (=TWAT) VII (red. J. Botterweck - H. Ringgren) (Stuttgart: Kohlhammer 1995) 93-101.

Klein, A., Schriftauslegung im Ezechielbuch. Redaktionsgeschichtliche Untersuchungen zu Ez 34-39 (BZAW 391; Berlin - New York: De Gruyter 2008).

Koehler, L. - Baumgartner, W., Hebräisches und Aramäisches Lexikon zum Alten Testament (Leiden - New York - Köln: Brill 31995) I-II.

Lyons, M.A., From Law to Prophecy. Ezekiel's Use of the Holiness Code (LHB/OTS 507; New York - London: T\&T Clark 2009). Milgrom, J., „Leviticus 26 and Ezekiel”, The Quest for Context and Meaning. Studies in Biblical Intertextuality in Honor of James A. Sanders (red. C.A. Evans - S. Talmon) (BInterpS 28; Leiden - New York - Köln: Brill 1997) 57-62.

Nihan, C., From Priestly Torah to Pentateuch. A Study in the Composition of the Book of Leviticus (FAT II/25; Tübingen: Mohr Siebeck 2007).

Obinwa, I.M.C., "I Shall Feed Them with Good Pasture" (Ezek 34:14). The Shepherd Motif in Ezekiel 34: Its Theological Import and Socio-Political Implications (FzB 125; Würzburg: Echter 2012). Pardee, D., „The Ba'lu Myth”, The Context of Scripture. I. Canonical Composition from the Biblical World (red. W.W. Hallo) (Leiden - New York - Köln: Brill 1997) 241-274.

Pikor, W., Rola ziemi w przymierzu Boga z Izraelem. Studium historyczno-teologiczne Księgi Ezechiela (Lublin: Wydawnictwo KUL 2013).

Pikor, W., Soteriologiczna metafora wody w Księdze Izajasza (Studia Biblica Lublinensia 4; Lublin: Wydawnictwo KUL 2009).

Renaud, B., Nouvelle ou éternelle Alliance? Le message des prophètes (LD 189; Paris: Édition du Cerf 2002). 
Renz, T., The Rhetorical Function of the Book of Ezekiel (VT.S 126; Leiden - Boston - Köln: Brill 1999).

Sedlmeier, F., „«Ich schließe für sie einen Bund des Friedens» (Ez 34,24; 37,26). Visionen des Heils im Ezechielbuch", Inquire pacem. Beiträge zu einer Theologie des Friedens. Festschrift für Bischof Dr. Viktor Josef Dammertz OSB zum 75. Geburtstag (red. F. Sedlmeier - T. Hausmanninger) (Augsburg: Sankt Ulrich Verlag 2004) 42-69.

Sedlmeier, F., „Transformationen. Zur Anthropologie Ezechiels”, Anthropologische Aufbrüche. Alttestamentliche und interdisziplinäre Zugänge zur historischen Anthropologie (red. A. Wagner) (FRLANT 232; Göttingen: Vandenhoeck \& Ruprecht 2009) 203-233.

Tooman, W.A., „Covenant and Presence in the Composition and Theology of Ezekiel", Divine Presence and Absence in Exilic and Post-Exilic Judaism. Studies of the Soffa Kovalevskaja Research Group on Early Jewish Monotheism (red. N. MacDonald I.J. de Hulster) (FAT 2.Reihe 61; Tübingen: Mohr Siebeck 2013) II, 151-182.

Zimmerli, W., Ezekiel 2. A Commentary on the Book of the Prophet Ezekiel. Chapters 25-48 (Hermeneia; Philadelphia: Fortress Press 1983; oryg. niem. 1969).

Ks. Wojciech Pikor, kapłan diecezji pelplińskiej, profesor zwyczajny nauk teologicznych, wykładowca na Wydziale Teologicznym UMK w Toruniu, rektor WSD w Pelplinie, członek Zarządu Stowarzyszenia Biblistów Polskich, moderator diecezjalny Dzieła Biblijnego im. Jana Pawła II. Opublikował m.in. książki: Soteriologiczna metafora wody $w$ Księdze Izajasza (Lublin: Wydawnictwo KUL 2009); Rola ziemi Izraela w przymierzu Boga z Izraelem. Studium historyczno-teologiczne Ksiegi Ezechiela (Lublin: Wydawnictwo KUL 2013); Odkrywanie siebie w dialogu z Jezusem. Narracyjna lektura Ewangelii wg św. Jana (Pelplin: Bernardinum 2014). 